\title{
J
}

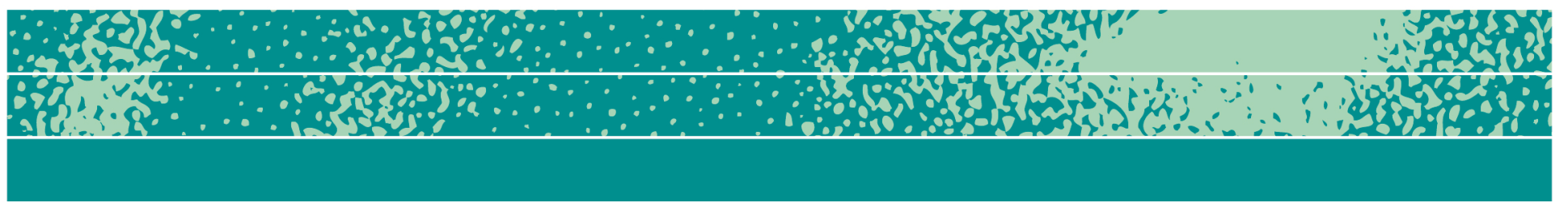

\section{Conflicting Interpretations: On Analyzing An Agribusiness' Concerns About Critique}

\author{
Tijo Salverda
}

\begin{abstract}
This article explores different ways to interpret the extent to which (capitalist) critique influences corporate practice. Starting from (self-) reflection upon negotiations between the author and a European company involved in land-based investment in Zambia, this contribution shows that corporate actors may be more responsive to their critics, such as NGOs, journalists, local communities, and (activist) scholars, than often assumed. It may be argued that anthropology partly misses this dynamic, due to its limited interest in ethnographic engagement with the powerful and its critical interpretations of capitalism. At the same time, with persistent unequal corporate advantages and wrongdoing, critical interpretations remain of significant relevance to understanding the limits of corporate responses. Reflecting on the balance between these different interpretations, the article aims to discuss the intricacies of analyzing and critiquing corporate practices.
\end{abstract}

Page 1 of 21

JBA 8(1): 4-24

Spring 2019

(C) The Author(s) 2019 ISSN 2245-4217

www.cbs.dk/jba

\section{Key words}

Corporations, critique, capitalism, self-reflection, Zambia 
Just after I arrived on the premises of a European agribusiness in the Zambian countryside in a late afternoon in May 2016, my phone rang. On the other end were two employees based at the agribusiness' European headquarters. Our conversation quickly became tense. To allow me to study its operations, we had agreed upon signing an agreement. ${ }^{1}$ Yet the conversation made it clear that we differed about the agreement's conditions. I was adamant that some ambiguous phrasing had to be taken out before I could sign, as it would hamper my academic independence. Conversely, my contacts at the headquarters appeared to worry about losing control over the extent to which the company could be identified in my publications.

The company's concerns are not unwarranted, as NGOs, local communities, journalists, and (activist) scholars, have increasingly criticized and opposed land grabs and food speculation around the world (Cotula 2012; Edelman and Borras 2016; Margulis et al. 2013; Ploeg 2010; Zoomers et al. 2016). Although the empirical evidence suggests that voicing these concerns has had some impact on land investors, including on the European agribusiness (Salverda 2018), entrenched capitalist structures do not easily change. Unequal balances of power emerge from large-scale agriculture, and market society remains entrenched. This lack of change makes it easy to see how critical interpretations of capitalism upon which many anthropologists rely, myself included - have persisted over generations. My observations in Zambia, accordingly, could easily confirm moral critiques of capitalism - an economic system characterized by a perpetual need for capital accumulation, commodification, and asymmetrical patterns of ownership. But could following this interpretive framework too strictly obscure additional insights into the position of corporate actors, and the influence critics might have in shaping the global capitalist economy?

In this contribution I reflect upon my personal experiences of negotiating an agreement with a European agribusiness, and the ethnographic interactions and observations that followed during several field visits between 2015 to 2018. My aim is to explore the intricacies of my own positioning, as well as analytical representation of corporate practices and its critique. I begin with methodological considerations, and how these relate to various interpretations of corporate responses to critique. Subsequently, I discuss my negotiations with the agribusiness, including challenges that I faced in interpreting and analyzing these interactions. I conclude with considerations about the various

\footnotetext{
${ }^{1}$ I had already visited the farm operation a number of times, yet once the discussion about the agreement came up, we agreed that I would first sign the agreement before visiting the operation again. Owing to some confusion over email, however, I had understood I could proceed to the farm, only to discover there that the European headquarters was of the opinion that I should not be there since negotiations had not yet been concluded.
} 
interpretations of the interactions and responses to critique.

\section{Interpreting Ethnographic Engagement with Corporations}

Given the commanding position of corporation in our global capitalist system, and their aim to secure and protect resources that are essential to sustaining their positions of market power, corporations are viewed as dominant societal forces. Ethnographically engaging with corporations is, accordingly, considered a form of "studying up" (Nader 1972; Sedgwick 2017). Although numerous anthropologists have successfully studied powerful actors (e.g., Ho 2009; Ortiz 2014; Ouroussoff 2010; Pina-Cabral and Pedroso de Lima 2000; Shore and Nugent 2002), leading to more or less critical analyses of corporate practices, ethnographers who engage with corporate actors are often perceived with suspicion (Peluso 2017). Does studying corporations means extending the same kind of sympathy that ethnographers typically extend to members of their host communities? Studying corporations may also conflict with "the view that anthropologists' work 'should do some good'” (Sedgwick 2017: 62, 68). Reflecting a widespread and ritualized disloyalty towards elites in anthropology (Gilbert 2015), there is instead a tendency in anthropology to refrain from engaging with powerful actors, whom many critical scholars seek to weaken in favor of greater social equality. ${ }^{2}$ In many analyses, consequently, the powerful mainly feature as abstract actors shaping the lives of subaltern research subjects.

In the face of binary oppositions, anthropologists studying corporate actors may, like a company manager torn between meeting production goals and dealing with moral judgments, be "caught up between scientific neutrality and social engagement" (Gallenga et al. 2016: 3). As I would rather argue, anthropologists studying corporate actors are caught up between various ways of interpreting ethnographic observations. ${ }^{3}$ Following up on observing the limits of (global) market society (e.g., Gudeman 2008; Hart et al. 2010; Klein 2014), despair often prevails. Many examples clearly and convincingly demonstrate capitalism's negative impacts on class inequalities (Burawoy 2015; Carrier and Kalb 2015; Piketty 2014), environmental degradation (Kirsch 2014), and exploitation (Prentice and De Neve 2017). Though these issues are certainly real, we must also be aware that our analyses may be partly (and/or unconsciously) shaped in relation to the most critical and visible voices in the discipline. Scholars engaging with powerful actors may subsequently compensate for the worry of being perceived by

\footnotetext{
${ }^{2}$ See Graeber (2016) for an insightful discussion on the politics of anthropology.

${ }^{3}$ Solid ethnographic research, moreover, does not necessarily contradict a normative stance, such as most explicitly expressed in activist ethnography (e.g., Hale 2006; Juris 2008; Juris and Khasnabish 2013; Urla and Helepololei 2014).
} 
disciplinary peers as ideologically sympathetic for the powerful, as being naïve, and/or justifying capitalism. Critically reflecting upon the ethnographer's position vis-à-vis their (imagined) anthropological peer groups is thus also required. ${ }^{4}$

There are certainly valid concerns regarding ethnographic engagement with elites. Obligations and requirements that come with ethnographic encounters in general (Josephides 2015), for example, may equally apply to ethnographic analyses and encounters with powerful actors, including corporations. In the case of studying elites, moreover, Marcus (1983: 23) suggests that although empathy for one's subjects should not be misconstrued as ideological sympathy, "ideological distancing from one's subjects, to the point of disapproval, is a difficult condition of work in an ethnographic style of research [...]."

Notwithstanding such limitations, I would argue that anthropology might also miss constructive insights when ethnographic engagement with corporate and other powerful actors is discouraged. Stemming from my ethnographic engagement with the European corporation, for example, it seems that corporations may be more concerned with moral questions than is often assumed. This observation resonates with a long history in which moral and ethical considerations have shaped the directions of capitalism (Sampson 2016).

I do not reject pessimistic analyses of corporate power and wrongdoing, or what Ortner (2016: 49) characterizes as dark anthropology "that emphasizes the harsh and brutal dimensions of human experience, and the structural and historical conditions that produce them." Yet more than anthropology often acknowledges, ethnographic research with elites reveals that they have at times also had to defend their position from less powerful groups. In other words, elites power may be less or more tenuous than assumed, while "weaker" actors may have more power than is commonly recognized (Salverda 2010, 2015; Scott 2008). As Boltanski and Chiappelo (2005) argue, however, this has only led to minor tweaks to the capitalist system, rather than its complete overhaul or overthrow. Boltanski and Chiappelo argue that capitalism is able to incorporate critique, to the extent that it is virtually "neutralized"; capitalism includes enough critique to (temporarily) silence critics, but includes too little to cause significant change. This does not imply, however, as Chiapello (2013) points out, that all remains the same; critique may result in new organizations of capitalism - although the unequal tendencies of capital accumulation remain intact. Even if the structural core of capitalism is not dismantled, critics may nonetheless reverse some of its worst excesses. The abolition of slavery, for example, shows "that capitalism of its own accord contains little in the way of resistance against inhumane practices, but that it is compatible with such

\footnotetext{
${ }^{4}$ See about the positioning of the anthropologist herself, also Cefkin 2017.
} 
resistance when subjected to legal-political restrictions and guidance" (Kocka 2016: 70).

Capitalism may be more like a continuum, ranging from severe oppression resulting from an unbridled aspiration to accumulate capital, as in episodes of "primitive accumulation" (DeVore 2018), to societies with much fairer distributions of capital and wealth, as in European social democracies. ${ }^{5}$ Public critique has contributed significant in push corporate actors toward more egalitarian and just distributive outcomes; critique makes "it possible to link the good fortune of the great men to the misfortune of the little people, and to instill in the former a sense of responsibility for the lot of the less privileged" (Boltanski and Chiapello 2005: 518). It is thus of relevance to probe how powerful actors interact with critique, and related requests, to instill a sense of responsibility. It appears that corporations often initially oppose critics' demands, because they perceive them as external to the capitalist logics of market relations (Benson and Kirsch 2010). Over time, however, they may (partly) adapt, genuinely embracing or appropriating certain concerns. Although such accommodation can be viewed cynically, in the sense that corporations only respond to "selfish" to concerns with utility maximization (Gallenga et al. 2016: 1), corporate actors' initial opposition does not mean that company executives are by definition cynical in pursuing social causes (Bloomfield 2017; see Frynas, in response to Benson and Kirsch 2010: 476), or unaffected by moral concerns (Browne 2009; Fourcade and Healy 2007; Hann and Hart 2011). Corporations are driven by profits, but not necessarily or always at all costs - or irrespective of society. Hence, even when (activist) scholars adopt normative and critical stances, an openness to politics without guarantees may be helpful. This may be "disturbing to people who still dream of a simpler, Manichean world of good guys and bad guys" (Maurer and Mainwaring 2012: 181), yet without such openness, the outcomes of aims to transform (or dismantle) capitalism may be obscured, however small the changes may be. That said, the extent to which change is observed perhaps always remains a matter of degree. If dismantling capitalism is the aim, Boltanski and Chiapello (2005) suggest that critique has so far been insufficient. Conversely, as Welker (2014: 217-218) argues, when activists succeed in improving worker compensation, or stopping toxic dumping by a mining company, meanwhile falling short of larger goals such as closing the mine, nevertheless " $t]$ he corporation has budged, becoming something other than what it was". Proceeding from these various viewpoints, the "right" analytical balance may not always be self-evident, as I show in the following section through reflections upon my own negotiations with the

\footnotetext{
${ }^{5}$ The original sentence, which Hannah Appel cites in her comment, was "Maybe capitalism is more like a continuum, ranging from the most severe oppression resulting from the aspiration to accumulate capital, on the one side, to a society with much fairer capital distribution, on the other."
} 
European agribusiness.

\section{On Zambian Ground}

In 2012, the European agribusiness began operations in Zambia, after it had purchased about 38,000 hectares of titled land - of which they have developed about 5,000 hectares. Three years later, in 2015, I first visited their operations. By then, the agribusiness was in full operation and fit the stereotype of a large-scale land-based investment in Africa. I observed, on the one hand, a corporation with expensive machinery, well-paid managers, and refrigerators filled with food and drink. On the other hand, I observed that rural residents were mostly living in simple huts with no electricity, mainly eating from what they could produce from their land. Was this the sort of inequality that perfectly and visibly confirmed the limits of capitalism? Perhaps. But it was probably also the sort of poverty and inequality that was beyond the ability of a single corporation to reverse, especially in a country where the state has difficulties providing for its citizens, even if it should be pressured to do more in that direction. For example, discrepancies between the salaries paid to expatriate managers and European directors, and salaries paid to Zambian laborers, even when they are in line with Zambia's minimum wage laws, could be more explicitly considered by the institutional development agencies with which the company collaborates.

At the same time, I observed that the corporation considered it important to maintain good relations with neighboring communities. This seemed partly a response to global counter-movements voicing concerns about "land grabbing" (Salverda 2018). For example, the land purchased by the company was not completely uninhabited, indeed, a number of smallholder farmers squatted on the land without formal legal rights. For these smallholders, the status of the land was unclear, because much of the titled land had previously been in the hands of absentee landlords or was only partially used. As a result, some local families were residing on the land when the European company purchased it. As far as I could tell, the company handled a number of resettlement cases carefully, probably due to its own moral convictions, but also to minimize tensions with the local communities and forestall complaints from critics. In the resettlement cases, moreover, the company relied on various international guidelines that had been developed in response to global critiques. Although the voluntary character of these guidelines has, for very valid reasons, been criticized (Borras and Franco 2010), in Zambia they appear to have had positive impacts on the ground. The affected families, for example, were provided with small plots of titled land which they did not have before - as well as promises from the company to help them construct brick houses on their new plots.

Other activities that the company developed, such as supplying 
local schools and classrooms with electricity, would probably qualify as a Corporate Social Responsibility (CSR) response. CSR can be legitimately criticized owed to its limited impact, and/or its appropriation by corporate agendas (Gilberthorpe et al. 2016; Rajak 2011). CSR is, for that matter, an insightful example of the ambiguous impact of critics. Would it not for the critics, corporations would have felt less obliged to initiate CSR, as it was initially developed in response to external criticism (Dolan and Rajak 2016; Kirsch 2016). Yet it is also a telling example of the fact that, although capital may respond to critique, the kind of improvements proposed by CSR do not, at the end of the day, tend to reverse existing inequalities. Despite the limited impact, global corporations often consider the slightest adaptation to criticism as a substantial ethical turn (Gilbert 2015; Welker 2009). In light of this, it is important to realize that, in the case discussed here, the company's employees, as well as other involved actors, often consider the company's main critics as being highly selective in their arguments. ${ }^{6}$ Yet these critics may nevertheless have some impact, as the corporation's interactions with the rural residents, including its CSR activities, are partly shaped through reflection upon the (general) concerns they raise. Interestingly, in the years after its initiation, the company's approach has even received positive exposure, as various (institutional) actors in Zambia and Europe have come to consider the corporation as a relatively enlightened example of landbased investment. In 2016, even a staff member of the critical NGO acknowledged that the company was more open in its engagement with surrounding residents than other corporations. Yet, for reasons that equally affect my analysis of the company, he pointed to an issue that also warrants a level of concern.

The main investor in the company has a tarnished reputation in his home country. The structure of his investment fund, which includes

\footnotetext{
${ }^{6}$ This is particularly the case of an NGO from company's European home country, which has openly associated the agribusiness with land grabbing. According to the NGO, land grabbing is also about the concentration of large tracts of land in the hands of a few, because this potentially limits the land available for the most vulnerable actors, the rural populations - even more symbolic in case of a foreign investor. The NGO's main aim is to defend the right to food, and since a large investor may limit local population's access to food sources and production, it is of lesser concern whether or not the land is titled or not. In addition, the NGO also presented a higher number of locals that had to be resettled than the investor claims. Whether or not this has been the case indeed has been difficult to find out. It was difficult to trace all the sources the NGO report referred to, yet from what I could gather, the report did not seem to have made up numbers. The sources it relied upon, though, may have provided incorrect numbers (a problem witnessed more often in the large-scale land acquisition debate, as Brautigam and Stensrud Ekman 2012 illustrate). According to the company, moreover, the NGO had not distinguished between groups that were affected by the project, but not subject to resettlement, and the group that had been resettled. Grouping them together as if they were all subject to resettlement presents a distorted picture according to the company.
} 
investments in other domains beyond its agricultural acquisitions in Zambia, is characterized by financial complexity and confrontations with other investors - who believe the fund does not fulfill its promises. With only part of the land developed, the agribusiness might instead, according to the NGO staff, be a front for speculation, with an ulterior aim of selling the land at some point in the future. Although the corporation's management and PR group always stress the company's long-term engagement, it is also possible that the company's treatment of the surrounding communities and its workforce is largely driven by the public relations aim to present a favorable image. Whether or not this is necessarily a bad thing is open to debate, since rural residents' conditions could still improve as a result, even if the company's intentions are not "genuine". Yet, the possibility that the corporation's activities might serve ulterior motives, looming financial problems also create a certain level of suspicion, as I will discuss below. The challenge, accordingly, is how to navigate the thin line between the anthropologist's descriptive tasks, and, in this case, speculating about the company's future. Although there are certainly factual observations that warrant suspicion, at the same time it is necessity to sustain a certain measure of analytical skepticism that may not always be sustained by tangible empirical evidence, in case future realities depart from earlier assessments and analysis.

\section{A Welcoming Approach - Initially}

In 2015, my access to the agribusiness' Zambian operations were secured by verbally assuring the then head of the sustainable development that I would keep the company anonymous in my work. Responding to my explanation of my research aims, this manager said, "I just hope you write good things about [us]." This welcoming attitude from the manager and other employees appeared genuine, contrasting with the notorious difficulties of studying corporations ethnographically. A year later, however, when I met her replacement at an agricultural trade show in Zambia, I had to renegotiate the process of gaining access all over again. Although it proved more difficult this time, it also turned out to be informative with respect to relationships between the corporation and its potential critics, generally. On the one hand, I was a researcher who might be a potential critic, or whose publications could offer ammunition to the company's critics. On the other hand, the corporation was concerned about the impact critics might have.

One of the main concerns expressed by the new sustainable development manager emerged from the potential for bad publicity, as well as the apparent hidden agenda of researchers engaging with the company. By the time we met, a new publication had appeared from a Zambian research institution, which was published in collaboration with researchers from the company's country of origin. Unlike the NGO 
mentioned above, the researchers had visited the farm in collaboration with the company. However, the sustainable development manager considered the facts presented in the publication to be rather selective. She told me that they did their best to be open and welcoming with the researchers, but that they were somewhat disappointed to receive a critical publication in return.

Although I did not find the publication unfairly critical, it is relevant to consider the manager's concerns for a moment. To a certain extent, she may have been right that some positive developments were left out of the publication. Parts of the report's analysis, which had not anonymized the corporation, were more general in nature than directly relevant to the company's Zambian project. For example, it rightly suggested that land-based investments should engage surrounding communities, yet it hardly mentioned that the company was doing this already. Nevertheless, an interviewee with knowledge about the case considered the publication of relevance: even if it may not have been completely accurate, it keeps the corporation in check, in the sense that it knows it is being watched.

Some reluctance from the corporation's side to engage with potential critics may nevertheless be understandable, and should not a priori be interpreted as if they have something to hide - although, as I will demonstrate below, they may sometimes have something to hide. In the same manner that I maintain a level of skepticism toward the Zambian project, the corporation may be reluctant to authorize my access to their activities. In response to the sustainable development manager's question concerning what publications were expected to result from my research, for example, I could only answer that I did not know exactly what and when anything would be published - I was not expecting this publication, for example - but that in return for their collaboration, I was willing to share my articles with them before publication.

On more or less the same ground as the previous year, I was again granted access in 2016. I reconfirmed that the company would be referred to anonymously in my publications, and I assured the manager that I was not merely seeking to name and shame the company. Instead, I wanted to understand the investment in all its complexities. A few days later, I received an email from the manager in which she confirmed my visit and what we had discussed at the agricultural fair. To my surprise, however, she also included a reference to the company's legal department. When I received the draft agreement a week after, however, the agreement on paper turned out to be much stricter than what I thought we had previously discussed.

My initial thoughts turned to whether the corporation had something to hide. If so, would it not have been more logical to prevent me from visiting the farm to begin with? It is more plausible is that the 
corporation was balancing a desire to be open with an awareness that researchers may come to different conclusions than they do concerning their own activities. My view is that such companies they are particularly worried about negative publicity insofar as this could potentially limit the availability of new capital by attracting new investors. It could accordingly be argued that one "success" of global critics is that many (institutional) investors are nowadays concerned with the social impact of their investments, and may shy away from investing in projects that could cause reputational damage - even a relatively unknown anthropologist may affect this process with an online publication. In response, the corporation seemed to reassess its open engagement with scholars and other potential critics. ${ }^{7}$

\section{Mounting Tensions}

What the process of coming to an agreement illustrates is that it is a process of give and take, while protecting what is at stake for both sides. For example, I agreed, among other requirements, to anonymize the corporation's country of origin. There are not many land-based investors from this country in Zambia, and thus a Google search could easily link my publications to the corporation. In exchange for substantial anonymity, however, I argued that my obligations toward the academic community entail that I should maintain full control over my publications - the company was allowed to fact check, but I could not be demanded to include changes. Initially, however, the company was not willing to concede on this issue. In an email, the manager stated that there was actually not much room left to negotiate: "... [t]his is the absolute bare minimum from our side." With the help of my university's legal department, I nevertheless presented a revised version of the agreement, which covered my concerns and removed some of the more ambiguous phrasing. Due to some miscommunication with the sustainable development manager, it was only when I arrived for another visit to the company that I understood that they did not agree with the suggested changes (we had agreed to postpone a follow-up visit to the farm until we came to an agreement).

In particular, a reference to "any distinguishing features" in the anonymity clause turned out to be a matter of increasing tension that afternoon. They wanted to know in advance what distinguishing features could appear in my writings, while I wanted to avoid the potential that

\footnotetext{
${ }^{7}$ When I visited the sustainable development manager at the European headquarters a few months later (also in 2016), she explained that she had asked a contact working in a similar function for a multinational sugar producer how they dealt with research and/or visiting requests. The answer she received was that it was better not to refuse requests, although the signing of some sort of agreement would be demanded in return.
} 
any kind of feature could later be deemed a "distinguishing" one. Consequently, I refused to sign an agreement in which this restriction was included. To accommodate me, they instead suggested changing it to "names of investors, recent acquisitions, and third/contractual parties." Although anonymizing a few that we explicitly named, such as neighboring communities and chiefs, I considered a reference to third or contracting parties equally vague and restricting. It would be difficult to foresee what the corporation could consider as a third or contracting party in the future, and the extent to which this would complicate my analyses.

The managers argued that they had already conceded much in relation to the original agreement. I countered that the first draft they sent me was much more restrictive than what had originally been discussed, both with the new and former sustainable development manager, and that I had already made many concessions. I stressed that their anonymity well covered, and that my publications could not be easily linked to them in Google searches. These guarantees did not bring us any closer. Instead, they suggested that they needed to sleep on it, or rather that I should sleep on it, because the development manager stressed that they would not concede. When giving it further thought that evening, however, I decided that I would not sign anything beyond what I proposed together with my university's legal department.

The next morning, it initially appeared that management would stick to their position. In an email, the sustainable development manager stated that the company accepted that I would have "the rights to publish after making reasonable effort to resolve any dispute." The distinguishing features had also been taken out, and replaced instead with a specific list referring to "investors, acquisitions, community." However, I could still not name cooperating partners without prior written consent, apart from government boards and agencies. The email ended with: "As you know, we are open and transparent with information and have nothing to hide, but this is the most basic form of protection for us. Looking forward to your feedback this morning so we can decide whether to proceed or not." I replied that I was by and large fine with the changes, but that I would not sign for the cooperating partners. I would accept a number of constraints, because I could understand the company's position. But I only agreed to very specific definitions, rather than highly general definition that would make it difficult to foresee whether or not they would have consequences for my future work. I stressed that I was already of the opinion that we had reached a reasonable compromise: their anonymity would be guaranteed, while I would keep my academic independence. It would be up to them to decide, I argued, whether or not the cooperating partners clause was really that important. If so, we would not come to an agreement.

To stress my position, I wrote that I had enjoyed the collaboration 
so far, that it would be unfortunate if they would not sign, but that I could also continue the research with neighboring communities and other relevant parties. In that case, however, all anonymity clauses apart from the company's name would be taken off the table - I would respect the fact that I had verbally agreed to anonymize the company's name. Shortly afterwards, another email came in: all my suggestions were accepted and thus we came to an agreement. I believe, in hindsight, that it helped to suggest that I would walk away from the agreement, and continue to study the company without its cooperation and anything other than a verbal anonymity agreement. The company appears to have realized that publications in which it would easily be identified, but had no voice, might do more harm than signing a "lighter" version of the agreement. This is an illustration, in my opinion, that the corporation was not oblivious to its critics.

\section{What to do with an "insider"?}

Though it is evident that the agribusiness has been concerned about critics' (potential) impact, the proof is in the pudding, so to speak - both regarding the impact on the ground, and the (dis)advantages of the agreement I signed with them. A closer look at the agribusiness' commitments to the rural residents shows that the outcomes have been ambiguous. Numerous locals I spoke to appeared content with the arrival of the European agribusiness, since it provides employment and a market in an area where there was previously little of either. Yet, not only do local residents earn relatively little, especially compared to the (expatriate) management class, the company has also been slow in fulfilling a number of its commitments, such as the building of houses and the drilling of boreholes in the case of the resettled residents. A number of these residents have rightly complained about these delays, which seem to have had some impact. During my successive visits, I observed that there was always progress compared to my previous visits. Still, not all commitments have been fulfilled, so a level of dissatisfaction remains justified, especially as such dissatisfaction appears to be caused by financial difficulties.

I have the impression that my interactions with the company after signing the agreement in 2016 have been marred by the company's financial situation. In particular, the European headquarters has expressed some reluctance to continuing the ethnographic engagement. In 2017 , for example, the head of sustainable development management at the European headquarters was not very open to me visiting the Zambian operations. With what turned out to be dubious arguments about the unavailability of accommodation at the farm in Zambia, she may have wanted to discourage my ability to conduct research on site probably because of the departure of my main Zambian contact at the 
farm, the local sustainable development manager, and problems in fulfilling its financial and other commitments. In Zambia, however, I discovered that there was indeed accommodation available, and through my contacts, I was nevertheless able to spend some time at the farm. This allowed me to obtain interesting insights, for example, from people who sold land to the company but had still not been paid - a situation made more complicated by the thorny and lengthy process of land registration in Zambia. Yet questions I later posed about the company's financial difficulties were met at the headquarters with unsatisfactory answers and continue to be avoided, despite the fact that in 2018 even the Zambian management confirmed the difficulties. The sustainable development manager categorically denied any financial difficulties, and, in 2017, stated that she could not answer certain questions because they were about the company's internal operations. Our relationship was further affected when she later found out that I had stayed on the farm, although she had communicated to me that there was no accommodations available. Furthermore, later that year when I sent her an article accepted for publication (Salverda 2018), which, as we agreed, she could read prior to being published, we had to deal with conflicting interpretations of the company's behavior.

The outcome of the article is in itself relevant to balancing of various interpretations. On the one hand, my argument is shaped in accordance with existing (critical) theory, scholarly feedback, and, possibly, the manner in which I imagine my intended audience. Largescale foreign land investment is a politically contested topic, as the article reviewers' comments demonstrated. Though I did not fully agree with one reviewer who argued that a company would only respond to social demands according to "cost-benefit calculations", I may have (unconsciously) moderated or left out certain aspects of the company's operations, while stressing others. Further nuances have been lost, as anthropological models and theoretical frameworks can have distorting effects, "as theoretical straitjackets for shaping ethnographic 'facts'" (Josephides 2015: 11). With the aim of publishing in a critical journal, to gain respect from fellow scholars, my focus may have also been on critiquing capitalist enterprises rather than focusing on positive developments - to the extent that I might have even "hoped" the investment would have little positive impact, so I could safely confirm the limitations of capitalism.

On the other hand, following Josephides' (2015) insightful account of the obligations and responsibilities of ethnography, a level of responsibility towards my research informants might have affected my analysis. The head of the sustainable development section may think differently, and instead view the article as the unintended outcome of a learning process. Initially, through their openness, the agribusiness wanted to demonstrate that it acted more fairly than many other land- 
based investments. Yet even if this were the case, the article was another confirmation that not everyone would agree with their PR story, and that the company might be vulnerable in the face of criticism that could, for example, hamper its ability to attract investors.

I have to be frank about the possibility that, resonating with Josephides (2015), company employees may feel somewhat "betrayed." In particular, and partly understandably, after reading the article the sustainable development manager was of the opinion that I presented a rather one-sided story that focused predominantly on the role of critique. According to her, I hardly addressed the company's positive contributions in the area, and had included a number of suggestive arguments that were not backed up by empirical evidence.

In certain instances, she had a point. It appeared indeed that I had too easily included a few statements that fit my argument, but had little empirical substance. Moreover, we can ask if the company and/or its employees' attempts to improve local conditions should automatically be dismissed when they do not share concerns about, or are not aware of, certain structural limitations addressed in critiques of capitalism. Furthermore, as the writing of the article showed, critiques often only develop gradually, with additional questions and insights emerging during the process of fieldwork, and later through analysis and writing. Thus, the eventual output and possible critiques may not be what the corporation - or even the researcher - imagined at the time of discussing access. Corporate actors should be able to understand this, as the outcomes of their own investments often equally diverge from initial intentions. Hence, it could be argued that protecting the image of the corporation also results from uncertainty about what will eventually be published.

The sustainable development manager's comments, nevertheless, were also very illustrative of the need to remain very skeptical of the image corporations aim to present. The company's (PR) story was equally one-sided and deprived of nuances, with only references to its good intentions. Sometimes, the managers arguments that the company mainly acted in the interest of the rural residents made a caricature of the company. Thus it is ironic when a company manager presents a rather selective account (and selectively shares information) of their operations, meanwhile they "accuse" scholars investigating the company, including me, of being selective in their analyses.

\section{Conclusion}

Although there is sometimes truth to be found in dichotomies, simplified abstractions of corporate power that reduce to opposing sides do not appear to be very helpful. Nonetheless, as my reflections demonstrate, the extent to which corporations respond to demands to reverse inequalities 
and power imbalances may be somewhat tricky to investigate. Finding a balance between different interpretations is not easy and marred by doubt: one moment I observe positive developments, yet a moment later it is the reverse. Hence, at the same time as it is important to critique the critique (of capitalism), one has to also (try to) confront one's own blind spots.

Methodologically, and following suggestions from colleagues who argued against the anonymity I agreed to grant the company - the ones in power do not need protection in the form of anonymity, so the argument goes - it is valid to ask whether or not signing of agreement contributed to obtaining better scientific insights. With the company hardly being open about its (financial) decision-making, yet somewhat protected due to the anonymity clause, this has become even more pertinent. The company's anonymity may hamper other scholars to verify or falsify my analyses through further field research, although there is nothing that prevents me from naming the company when they ask, as the agreement is only about my writings. But I do not discount that I may come to consider the agreement too restrictive, in particular the anonymity about its European country of origin, for what I receive in return.

For now, however, I believe that through my ethnographic engagement with the company, I have been able to better understand the relations between a corporation and its critics, of which the agreement was itself symbolic. More abstract interpretations of powerful actors would probably obscure some of the nuances involved and, accordingly, only tell part of the story. In this sense, ethnographic engagement with powerful actors, such as corporations and elites, should be an additional component in our understanding of Ortner's dark anthropology, if only in order to better understand the ideological frameworks and practices of the powerful that many (activist) scholars aim to challenge.

Analytically, the case demonstrates the intricacies of balancing different interpretations. It may be virtually impossible to strike the "right" analytical balance, since tensions between openness to engagement and seeing commonality and confronting inequalities will probably always remain. Based on the same evidence, the eventual conclusions seem to be a "matter of degree": whether one concludes that capitalism only incorporates a part of the critique, or that corporate actors are more responsive to their critics than we assume, depends on one's emphasis. I am equally aware of the many limitations that remain, and neither do I deny that critics have so far only scratched the surface of dismantling capitalism, if at all it is clear what overthrowing capitalism would entail exactly - and in many instances this is probably also not the critics' aim. Since there has yet to be a reverse of inequality and/or power relations, the outcomes in the case presented here may thus be similar to what Theodossopoulos (2014: 425) argues in the case of resistance: though it may lead to change, the disempowered often remain 
disempowered in their everyday lives. Maybe all critique and/or resistance can do is to prevent the situation from getting worse, so to speak. Yet, at the same time, examples such as the abolition of slavery and labor movements in much of the Western world during the first half of the twentieth century indicate that substantial transformation is possible.

That said, what the critics will eventually obtain is probably not utopia but a compromise. In balancing between different interests, corporations and other elite actors certainly have more power to shape the directions of the social world than others, and are better positioned to reclaim powerful positions in a transforming world. As CSR illustrates, they are also able to slow down processes of transformation. Yet they cannot do as they please; they are neither oblivious to society's needs, nor immune to criticism. Although still within the frame of capitalism, in response to critique, no market operator wants to be the first to offer a "good life" to increasingly disempowered actors, as this may jeopardize the operator's competitive position (Boltanski and Chiapello 2005: 19). Yet in the long run, according to Boltanski and Chiapello (2005), the "capitalist class" as a whole has an interest in retaining the commitment of those on whom profit creation depends. Hence, they cannot indefinitely ignore calls for building a world common to us all, notwithstanding that eventual transformations may be less than what many have hoped for.

\section{References}

Benson, P. and S. Kirsch. 2010. 'Corporate oxymorons'. Dialectical Anthropology 1: 45-48.

https://doi.org/10.1007/s10624-009-9112-y

Bloomfield, M.J. 2017. Dirty gold: how activism transformed the jewelry industry. Cambridge, MA: MIT Press: Boltanski, L. and E. Chiapello. 2005. The new spirit of capitalism. London and New York: Verso Books.

Boltanski, L. and E. Chiapello. 2005. The new spirit of capitalism. London and New York: Verso Books.

Borras, S.M. Jr. and J. Franco. 2010. 'From threat to opportunity? Problems with the idea of a "code of conduct" for land-grabbing". Yale Human Rights and Development Journal 13(2): 507-523.

Brautigam, D. and S-M. Stensrud Ekman. 2012. 'Briefing rumours and realities of Chinese agricultural engagement in Mozambique'. African Affairs 111(444): 483-492. https://doi.org/10.1093/afraf/ads030

Browne, K.E. 2009. Economics and morality: anthropological approaches. Plymouth: Altamira Press. 
Burawoy, M. 2015. 'Facing and unequal world'. Current Sociology 63(1): 5-34. https://doi.org/10.1177/0011392114564091

Carrier, J.G. and D. Kalb. 2015. Anthropologies of class: power, practice, and inequality. New York: Berghahn Books. https://doi.org/10.1017/CB09781316095867

Cefkin, M. 2017. 'Afterword: questions of an anthropology of and anthropology for business'. Journal of Business Anthropology 6(1): 121123. https://doi.org/10.22439/jba.v6i1.5320

Chiapello, E. 2013. 'Capitalism and its criticisms'. In P. Du Gay and G. Morgan (eds.) New spirits of capitalism? Crises, justifications, and dynamics, pp. 60-81. Oxford: Oxford University Press. https://doi.org/10.1093/acprof:oso/9780199595341.003.0003

Cotula, L. 2012. 'The international political economy of the global land rush: a critical appraisal of trends, scale, geography and drivers'. Journal of Peasant Studies 39(3-4): 649-680. https://doi.org/10.1080/03066150.2012.674940

DeVore, J. 2018. 'Scattered limbs: capitalists, kin, and primitive accumulation in Brazil's cacao lands, 1950s-1970s'. The Journal of Latin American and Caribbean Anthropology 23(3): 496-520. https://doi.org/10.1111/ilca.12380

Dolan, C. and D. Rajak. 2016. The anthropology of corporate social responsibility. New York: Berghahn Books.

Edelman, M. and S.M. Borras Jr. 2016. Political dynamics of transnational agrarian movements. Warwickshire: Practical Action Publishing. https://doi.org/10.3362/9781780449142

Fourcade, M. and K. Healy. 2007. 'Moral views of market society'. Annual Review of Sociology 33(1): 285-311.

https://doi.org/10.1146/annurev.soc.33.040406.131642

Gallenga, G., S. Sampson and J. Soldani. 2016. 'Business ethics: a double bind'. Journal of Business Anthropology special issue 3: 1-6. https://doi.org/10.22439/iba.v2i1.5004

Gilbert, P.R. 2015. 'Trouble in para-sites: deference and influence in the ethnography of epistemic elites'. Anthropology in Action 22(3): 51-61. https://doi.org/10.3167/aia.2015.220307

Gliberthorpe, E., D. Agol and T. Gegg. 2016. '"Sustainable mining"? Corporate social responsibility, migration and livelihood choices in Zambia'. Journal of Development Studies 52(11): 1517-1532. https://doi.org/10.1080/00220388.2016.1189534

Graeber, D. 2016. 'Reflections on reflections'. Hau: Journal of 
Ethnographic Theory 6(2): 5-9. https://doi.org/10.14318/hau6.2.003

Gudeman, S. 2008. Economy's tension: the dialectics of community and market. New York: Berghahn Books.

Hale, C.R. 2006. 'Activist research v. cultural critique: indigenous land rights and the contradictions of politically engaged anthropology'.

Cultural Anthropology 21(1): 96-120.

https://doi.org/10.1525/can.2006.21.1.96

Hann, C. and K. Hart. 2011. Economic anthropology. Cambridge: Polity Press.

Hart, K., J-L. Laville and A.D. Cattani. 2010. The human economy: a citizen's guide. Cambridge: Polity Press.

Ho, K. 2009. Liquidated: an ethnography of Wall Street. Durham and London: Duke University Press.

https://doi.org/10.1215/9780822391371

Josephides, L. 2015. Obligations and requirements: the contexts of knowledge. London: Bloomsbury Publishing.

Juris, J.S. 2008. Networking futures: the movements against corporate globalization. Durham and London: Duke University Press.

https://doi.org/10.1215/9780822389170

Juris, J.S. and A. Khasnabish. 2013. Insurgent encounters: transnational activism, ethnography, and the political. Durham and London: Duke University Press.

https://doi.org/10.1215/9780822395867

Kirsch, S. 2014. Mining capitalism: the relationship between corporations and their critics. Oakland: University of California Press.

Kirsch, S. 2016. 'Virtuous language in industry and the academy'. In C. Dolan and D. Rajak (eds.) The anthropology of corporate social responsibility, pp. 48-66. New York: Berghahn Books.

Klein. N. 2014. This changes everything: capitalism vs the climate. New York: Simon and Schuster.

Kocka, J. 2016. Capitalism: a short history. Princeton and Oxford: Princeton University Press. https://doi.org/10.2307/j.ctvc77kv8

Marcus, G.E. 1983. Elites: ethnographic issues. Albuquerque, NM: University of New Mexico Press.

Margulis, M.E., N. McKeon and S.M. Borras Jr. 2013. 'Land grabbing and global governance: critical perspectives'. Globalizations 10(1): 1-23. https://doi.org/10.1080/14747731.2013.764151 
Maurer, B. and S.D. Mainwaring. 2012. 'Anthropology with business: plural programs and future financial worlds'. Journal of Business Anthropology 1(2): 177-196. https://doi.org/10.22439/jba.v1i2.3941

Nader, L. 1972. 'Up the anthropologist - perspectives gained from studying up'. In D. Hymes (ed.) Reinventing anthropology, pp. 284-311. New York: Pantheon Books.

Ortiz, H. 2014. Valeur financière et vérité : enquête d'anthropologie politique sur l'évaluation des entreprises cotées en bourses. Paris: Presses de Sciences Po.

Ortner, S.B. 2016. 'Dark anthropology and its others: theories since the eighties'. HAU: Journal of Ethnographic Theory 6(1): 47-73. https://doi.org/10.14318/hau6.1.004

Ouroussoff, A. 2010. Wall Street at war: the secret struggle for the global economy. Cambridge: Polity Press.

Peluso, D.M. 2017. 'The ethnography of versus for question in an anthropology of/for business'. Journal of Business Anthropology 6(1): 8-23. https://doi.org/10.22439/iba.v6i1.5315

Piketty, T. 2014. Capital in the twenty-first century. Cambridge, MA: Harvard University Press. https://doi.org/10.4159/9780674369542

Pina-Cabral, J. d. and A. Pedroso de Lima. 2000. Elites: choice, leadership and succession. Oxford and New York: Berg. https://doi.org/10.4000/books.etnograficapress.1278

Ploeg, J. D. v.d., 2010. 'The food crisis, industrialized farming and the imperial regime'. Journal of Agrarian Change 10(1): 98-106. https://doi.org/10.1111/j.1471-0366.2009.00251.x

Prentice, R. and G. de Neve. 2017. Unmaking the global sweatshop: health and safety of the world's garment workers. Philadelphia: University of Pennsylvania Press. https://doi.org/10.9783/9780812294316

Rajak, D. 2011. In good company: an anatomy of corporate social responsibility. Redwood City: Stanford University Press.

Salverda, T. 2010. In defence: Elite power. Journal of Power 3(3): 385404.

Salverda, T. 2015. The Franco-Mauritian elite: power and anxiety in the face of change. New York: Berghahn Books. 
Salverda, T. 2018. Facing criticism: an analysis of (land-based) corporate responses to the large-scale land acquisition countermovement. Journal of Peasant Studies. https://doi.org/10.1080/03066150.2018.1439930

Sampson, S. 2016. 'The "right way": moral capitalism and the emergence of the corporate ethics and compliance officer'. Journal of Business Anthropology special issue 3: 65-86. https://doi.org/10.22439/iba.v2i1.5009

Scott, J. 2008. 'Modes of power and the re-conceptualization of elites'. Sociological Review 56(supplement 1): 27-43. https://doi.org/10.1111/j.1467-954X.2008.00760.x

Sedgwick, M.W. 2017. 'Complicit positioning: anthropological knowledge and problems of "studying up" for ethnographer-employees of corporations'. Journal of Business Anthropology 6(1): 58-88. https://doi.org/10.22439/iba.v6i1.5317

Shore, C. and S. Nugent. 2002. Elite cultures: anthropological perspectives. London and New York: Routledge.

Theodossopoulos, D. 2014. 'On de-pathologizing resistance'. History and Anthropology 25(4): 415-430.

https://doi.org/10.1080/02757206.2014.933101

Urla, J. and J. Helepololei. 2014. 'The ethnography of resistance then and now: on thickness and activist engagement in the twenty-first century'. History and Anthropology 25(4): 431-451. https://doi.org/10.1080/02757206.2014.930456

Welker, M.A. 2009. '"Corporate security begins in the community": mining, the corporate social responsibility industry, and environmental advocacy in Indonesia'. Cultural Anthropology 24(1): 142-179. https://doi.org/10.1111/j.1548-1360.2009.00029.x

Welker, M.A. 2014. Enacting the corporation: an American mining firm in post-authoritarian Indonesia. Berkeley: University of California Press. https://doi.org/10.1525/california/9780520282308.001.0001

Zoomers, A., A. Gekker and M.T. Schäfer. 2016. 'Between two hypes: will "big data" help unravel blind spots in understanding the "global land rush"?' Geoforum 69: 147-159.

https://doi.org/10.1016/i.geoforum.2015.11.017 
Tijo Salverda, Ph.D. is a university professor of social and cultural anthropology at the University of Vienna, Austria. His research focuses on elites and corporate actors, including how they perceive and respond to counter-power. Salverda's publications include The FrancoMauritian elite: Power and anxiety in the face of change (Berghahn Books, 2015), The anthropology of elites (co-edited with Jon Abbink, Palgrave Macmillan, 2013), and 'Facing criticism: An analysis of (landbased) corporate responses to the large-scale land acquisition countermovement' (Journal of Peasant Studies, 2018). The research presented in this contribution was conducted during a postdoctoral appointment at the University of Cologne's Global South Studies Center (GSSC), and was partly funded by a grant from the German Research Foundation (DFG). 